\title{
Business tourism - a sustainable form to relaunch Romanian tourism
}

\author{
Manuela Liliana MUREȘAN \\ The Bucharest University of Economic Studies, Bucharest, Romania \\ Bogdan Cristian CHIRIPUCI \\ The Bucharest University of Economic Studies, Bucharest, Romania \\ bogdan.chiripuci@gmail.com \\ Puiu NISTOREANU \\ The Bucharest University of Economic Studies, Bucharest, Romania
}

\begin{abstract}
Sustainable tourism should be achieved in a balanced environment with standards that guarantee the preservation of ecological balance and prevent overuse of resources, pollution and other negative environmental impacts. In Romania, the tourism as social and economic phenomenon integrates in the unitary economy of the country having the necessary conditions for enhanced development and optimization of the tourism fund's explotation. This paper aims to highlight different perspectives to relaunch tourism services and will be the identification of factors which contributing to the sustainability of the tourism business. In addition, there will be comparisons of competitiveness in travel and tourism sector in countries such as Bulgaria, Czech Republic, Hungary and Romania.
\end{abstract}

Keywords: travel, business tourism, economic competitiveness, relaunching tourism services.

\section{Introduction}

\section{Current context}

The twenty-first century is distinguished by a continuous and rapid change in all the fields of activity of the society. The individual is in the centre of these changes being assaulted by the multitude of information and technological innovation with which it must keep up. Therefore, one can see the importance of tourism and travels for the national economies from all over the world, not only regarding the economic growth and the creation of new jobs. Without doubt tourism appears also as a means of strengthening the social stability and the development of the community as well as the preservation of the culture, resources and heritage of a nation.

Europe will continue to be the favourite tourist destination worldwide, with a market share of $52 \%$ and statistics show that most of the trips abroad of the EU residents still take place within the EU and according to the forecasts of the European Parliament, the number of international tourists that come to EU will increase by 140 million per year until 2025. Currently the tourism sector in Europe is facing a series of new challenges, among which the digitization of the distribution channels, the development of the new sector of collaborative economy, increasing competition from cheaper destinations from the markets of emerging countries, changing of the consumer behaviour, the transition to an economy focused on experiences, the demand for high quality services for customers, the need to attract and keep qualified staff. Let us not forget the demographic changes and seasonal character and the conflicts in the vicinity of the EU borders, such as those from Ukraine and the Middle East, along with the terrorist threats and the crisis of the refugees, all have a 
negative impact on the tourism sector and require measures to counteract both at national level and at European level (The Commission for transport and tourism, 2015).

The tourist destinations need appropriate instruments to adapt and grow in the global market in continuous quick and competitive transformation. Thus, we can see from the international comparison of the national performances in tourism, from a research study published by the World Economic Forum (WEF) in the Report on competitiveness in PICBE | 1102 the tourism and travel sector of the year 2007. Table 1 below shows the general ranking of the countries which border on Romania and which have somehow a similar history, and table 2 analyses these comparisons more detailed, using three main indicators - the legal framework, the business environment, the human, cultural and natural existing resources, according to the own assessment methodology of WEF.

Table 1. Overall standings competitiveness for selected countries

\begin{tabular}{|c|c|}
\hline Country & Ranking \\
\hline Bulgaria & 54 \\
\hline Croația & 38 \\
\hline Czech Republic & 35 \\
\hline Hungary & 40 \\
\hline Romania & 76 \\
\hline
\end{tabular}

Source: World Economic Forum 2007.

This system of classification includes 124 countries and positions each country in comparison with the others, regarding their competitiveness in the tourism and travel sector. Namely, each country is given a position in the ranking between 1 and 124, according to the compliance with the criteria laid down by the WEF methodology. Thus, Romania ranks 76 of 124, after Bulgaria and the other selected countries.

Table 2. Comparison of competitiveness in travel and tourism sector based on key indicators for selected countries

\begin{tabular}{|c|c|c|c|}
\hline Country & Legal framework & $\begin{array}{c}\text { Infrastructure and } \\
\text { business environment }\end{array}$ & $\begin{array}{c}\text { Human resources, } \\
\text { cultural and natural }\end{array}$ \\
\hline Bulgaria & 66 & 56 & 41 \\
\hline Croația & 58 & 40 & 11 \\
\hline Czech Republic & 40 & 37 & 22 \\
\hline Hungary & 26 & 51 & 51 \\
\hline Romania & 87 & 74 & 71 \\
\hline
\end{tabular}

Source: World Economic Forum 2007.

It is considered that the factors responsible for the poor performance in relation to the legal framework are associated with government regulations, in particular in the field of the environment, health and safety, although it is likely that the outbreak of avian influenza may have had an influence for 2007. In the category of the criteria regarding the business environment/infrastructure, the weak aspects regarding the air and road transport infrastructure are considered to be responsible for the lack of competitiveness, while the weak aspects with regard to human resources and the public perception of the importance and value of tourism from a political and statistical point of view are responsible criteria from the human - cultural - natural resources category (The Master Plan for the Development of the National Tourism $2007 \quad-\quad 2026$, http://www.mdrl.ro/_documente/turism/studii_strategii/masterplan_partea1.pdf).

Without doubt, Europe remains the region with the most international arrivals also for 2015, due in large part to its rich cultural resources, world-class infrastructure 
conditions, tourism services, public health and hygiene conditions, and in particular due to the Schengen area, a space of large opening and international integration.

The Report on competitiveness in the sector of tourism and travel of the year 2015 shows us that the remarkable cultural sights of Europe are not evenly distributed between countries; this does not explain in whole the large gaps between the most and poorest performing countries, regarding the cultural resources. While all the European countries have a long history, some of them made more progress than others in the promotion of cultural sites to become a magnet for tourists, for example Spain that is leading this classification. We mention that when choosing a destination in Europe, the tourist is also interested in sporting events and entertainment, as well as the conferences, fairs and exhibitions, (MICE) to which he may participate during the stay.

For Romania, which ranks 76th, in 2007 in this general ranking of the competitiveness in the tourism sector, after more than 9 years, almost 10 years, ranks 66th, practically went up 10 positions. In table 4, we introduce the new positions of the countries analysed in 2007, for 2015.

Table 3. Overall standings competitiveness for selected countries

\begin{tabular}{|c|c|}
\hline Country & Ranking \\
\hline Bulgaria & 49 \\
\hline Croația & 33 \\
\hline Czech Republic & 37 \\
\hline Hungary & 41 \\
\hline Romania & 66 \\
\hline
\end{tabular}

Source: World Economic Forum 2015.

As we have described above this ranking system includes, for the year 2015, a number of 141 countries compared to the year 2007, when the classification has been carried out on a number of 124 countries. The ranking positions each country in comparison with all the others, regarding the competitiveness in the tourism and travel sector. Namely, each country is given a position in the ranking between 1 and 144, according to the compliance with the criteria laid down by the WEF methodology. Thus, Romania ranks 77th of 124 in 2007, after Bulgaria and the other selected countries, in our region, and now it ranks 66 (Report on competitiveness in the tourism and travel sector, 2015 http://reports.weforum.org/travel-and-tourism-competitiveness-report-2015/indexresults-the-travel-tourism-competitiveness-index-ranking-2015/), still behind these countries, but it is worth to be noted that among the countries listed, Romania is the only one that has climbed 10 positions in all this time for almost 10 years, as compared to the other countries who have climbed 3 positions, Bulgaria or Hungary who has dropped a position the a position, from 40 to 41 . The trend is good, but we have a lot to recover and without a strategy for the development assumed by the governmental, associative and business environment, we still have to wait for another 10 years to climb10 positions and we still won't get Bulgaria and Hungary, two countries that do not have our resources but which have understood what is needed in this sector of tourism in order to be competitive, sustainable and to attract tourists.

Table number 4 reconsiders the main indicators such as: legal framework, infrastructure and business environment, human, cultural and natural resources, which have been analysed in 2007, in order to see what new things have been brought in this segment of competitiveness in 2015. 
Table 4. Comparison of competitiveness in travel and tourism sector based on key indicators for selected countries

\begin{tabular}{|r|c|c|c|}
\hline Country & Legal framework & $\begin{array}{c}\text { Infrastructure and } \\
\text { business environment }\end{array}$ & $\begin{array}{c}\text { Human resources, } \\
\text { cultural and natural }\end{array}$ \\
\hline Bulgaria & 5,24 & $6,06+4,22$ & $3,44+1,96$ \\
\hline Croația & 6,00 & $6,35+3,65$ & $3,80+2,67$ \\
\hline Czech Republic & 5,71 & $5,44+4,35$ & $2,59+2,30$ \\
\hline Hungary & 5,79 & $5,02+4,28$ & $2,72+2,22$ \\
\hline Romania & 5,42 & $5,01+4,11$ & $2,70+2,07$ \\
\hline
\end{tabular}

Source: World Economic Forum 2015.

PICBE | 1104

Because the analysis methodology differs from the year 2007, we cannot mention now where Romania is situated depending on these indicators, but we can see looking at the figures in the table, that her rank is close to Hungary from the point of view of the infrastructure and business environment, amazingly also as human, cultural and natural resources, exceeding Bulgaria only at the indicator of the legal framework. The transition from the planned economy to a market economy, the economic crisis in the past few years, the profound wear of the tourism and treatment infrastructure in certain regions in the context of the decreasing investments have led to a swinging evolution of the number of tourists in the past two decades and to the current stage of our country. But no doubt the tourism sector in our country is in the process of development and positioning regarding the international competition, but also the sustainability of this segment. We have a lot of work to do on this chapter in order to exceed the neighbouring countries and to dream to approach the leading positions occupied by Spain, France and Germany.

\section{Purpose, objectives and results}

The main approach we have in this article is to deepen the knowledge of the economic crisis role in the tourism field, with particular reference to the business tourism as a sustainable form for revival of the tourist services in Romania. The objectives we have during the study are as follows: investigating the specialty literature dedicated to the tourism issues and to the economic methods used by the stakeholders for the development of the tourist services. The result of the research will show us the ability of the business tourism to be sustainable in the context of revival of the Romanian tourism.

\section{Methodology}

It represents a synthesis of the specialty literature in the field of tourism through the use of these methods: lecture review by which we will assess, explore, identify and analyse the specialized literature, as we shall also use the analysis on the contents of surveys, of the official analyses and economic international reports carried out by global organizations, economic public or private international institutions on the studied field. Therefore, we will enforce the comparative analysis on the relevance, on the value, the advantages and the limits of the studies, of the scientific articles and academic journals relating to tourism

\section{Business tourism}

The World Tourism Organization defines tourism as the journey carried out in the purpose of recreation, rest or for business, with major importance for the world economy, due to the complexity of the services that are involved. Theobald, (2009) describes tourism as a round 
trip, and in a more romantic way, Bran (1997) describes it as "the art of travelling for pleasure." All these definitions help us to be able to define the branch of business tourism, as follows: "Business tourism involves journeys registered as having purposes relating to the work of the people. From the most ancient times man has travelled for trade, so it can be said that it is one of the most ancient forms of tourism" (Davidson, 2005). The large definition of business tourism given by Davidson consists in a variety of distinctive forms of PICBE | 1105 business tourism among which he includes: travels of the individual for the purpose of business in general, daily travel to and from the place of employment located outside the area of residence of the worker, local, regional, and national conferences and meetings organized by the associations, companies and corporations, big congresses and international conventions, training and initiation courses, exhibitions, product launches, motivational tourism, the short term labour force migration, exchanges of students and teachers, the movement for the purpose of transportation of products to the market where they will be sold, the delivery of the products to the consumers, military services carried out in a place other than the base usually used, travels for charitable purposes, as well as travels of the people in the government for the benefit of the state.

We note that the factors that influence the choice of the organizers of a location for carrying out certain business events have in view mainly the places with good air links, with a high standard of facilities, which protect the environment and with an attractive image for the business tourist, a tourist with high expectations. Other factors that influence the choice are: the reputation and the image of a potential conference centre, the costs and the number of available accommodation places (Cristeanu, 1992).

The motivational factors for business travelling are different in relation with the consumers and customers, and also in relation with the various types of business tourism. Thus, for individual business travel the main factor of motivation in the choice of the type and the location for the journey is often linked to the interests of the company and its tangents with the chosen location. By analysing the market share represented by the consumers of business tourism we notice that it can be segmented according to a series of criteria, including: seasoning of travelling, their purpose, nationality, gender, the frequency of the travelling, age, the means of transport, the type of international or domestic tourism and the nature of the demand for the various types of business tourism. Considering the interests of the companies in the choice of the locations, we talk about sustainability, we think of a new form of progress, one that is responsible and positive, which represents the following 4 aspects: the ability to conserve natural resources, the importance awarded to the social aspect, cultural heritage and biodiversity; the nature of the strategy implemented in a holistic manner, but also taking into account the fact that the resources are increasingly fewer for the future generations (Lu and Nepal, 2009).

We can sustain that business tourism is rather an experience, than a product, its nature is reflected by: the ambient of the destination and of the accommodation space, the tourist personality and experience, which is linked to: the anticipation: (before the event), consumption (during the event) and the memory (after the event). It is to be mentioned that business tourism is not dependent on the distribution and the quality of the natural factors, of anthropogenic elements that generally attract tourists, but rather on the infrastructure and the diversity of the services offered, and the business tourists who participate in events, are more demanding, less interested in the cost given and more preoccupied by the statute, they being sophisticated consumers of first-class services. 
(Minciu, 2007) Because they are informed customers, they focus on sustainable development and they claim that the tourist services they are offered to comply with the basic principles of sustainability, in such a way as to live in a balanced environment.

If you want to make an assessment of the impact of the business tourism on the participants, we observe that we know very few researches or studies on which to rely on when making a statement; thus, not all the actors involved are affected evenly in the business tourism: there are great winners such as the big hotels by international brands and owners of successful event organising companies, as well as smaller winners, such as the personnel employed in the serving who have a low salary. It is clear that the impact of the business tourism on the economy and the society as a whole is positive, all the more that at the social level, it manifests as an active means of education, of raising the level of training of people by participating in the different meetings. During business trips, the tourist is stimulated by the exchange of values and by completing its cultural, informational and professional horizon. Also, the rational and efficient use of spare time by ways of recreation and pleasure has a positive impact on rebuilding of the psychic affected by work stress (Minciu, Zadig, 1984). We observe an intensification impact of the relations between nations by attendance at international diplomatic and governmental meetings.

Being an interactive industry and always competitive, the staff is relatively young, different as qualifications and attentive to details. According to Swarbrooke, Horner (2011) the skills that the staff in this industry has to meet are: communicability, attention to details, resistance to pressure and stress, openness to new things, knowledge of foreign languages, knowledge of PC operating and of the new smart technologies. Let us not forget that the success of this industry depends on the segment of consumers, according to Nistoreanu, (2005), the customer today is more educated, better informed, it is a modern costumer, to whom it seems normal that the tourist offer be correct, at a high-quality level, with a fair price-quality ratio and respect of cultural and natural resources. It would be ideal that the relationship between the client and the supplier, in the framework of the business tourism be as the "water cycle" (Nistoreanu, 2005), more exactly, to exist a good communication in such a way that the customer's wishes to be materialized by the products or services offered by the supplier.

The business tourism industry uses an infrastructure in continuous development and features that may be of use in many other purposes but, in order for them to meet the specific needs of the tourist who travels for business, they must be designed in a certain way, from private airports to hiring out a room equipped according to the latest technological standards. Thus, the infrastructure development requires the design of a whole series of elements in respect of a business tourism centre, for example: main buildings and secondary structures, the shape of the location taken as a whole, with a modern interior accessory, equipped with parking and fast access to public transport. The business centre must have support services such as the rental of cars by combining the means of transport, such as aircraft and car or renting a car with or without driver (Stanciulescu, 2002), but also catering and restaurant facilities. There can be no doubt that the business tourism, if it is well planned and led, may help to generate income for the local population and can accelerate the development of the region. 


\section{Revival of the tourist services}

The concept of revival is often used in marketing campaigns to give a new impetus, image, attention to a product / service existing on the market. Thus, according to the specialized literature, the tourist services are separated from the goods, determining the contents of the service as a distinct tertiary sector of the economy. In the majority of cases the focus is on the fact that the services are activities of which the result is immaterial and therefore non-storable. So in practice it is sometimes difficult to distinguish the services of goods whereas, frequently purchasing a good includes an element of service, as in a similar manner, a service involves most often the presence of tangible goods (Minciu, 2000). We observe that tourism has as its object to meet the needs of people arising on the occasion and during the journey, so, it can be regarded as a succession of services such as those of transport, rest and food, recreation etc. One part concerns the common everyday needs such as rest and food, and others are intended for certain specific tourism needs such as pleasure, treatment, even the acquisition of new knowledge. The tourist services may be the only of the tertiary sector which are not pure, having a complex content, being a combination of tangible and intangible elements. Therefore, the product is considered to be the result of the association between the attractiveness of an area (resources) and facilities (services) offered to the purchaser.

For revival of tourism through the business tourism industry, we need the exploitation of technology, which is continuously innovating and without which any sector of activity of the economy should be dead in the XXI century. The development of the internet and the access to this form of communication and information has begun to have a significant impact on the business tourism and its sustainability. It softens the differences between the promotion and distribution by the fact that it allows customers to obtain information and to purchase products at the same time (Getz, 2003). The development of technology also has implications on the tourist marketing in particular in the case of services granted to customers, in particular to business people, whose time is limited and means money, for example, the technology enhances the rapidity of checking the tickets online when boarding in an airport, without having to print them and allows the traveller to arrive later at the airport, without the risk of losing the flight.

The modernization and innovation of the reservation systems, in particular the development of the Global Destination System facilitates the detailed distribution of the business tourism regarding the fast and easy creation of complex itineraries at the request of the customers. Today more than ever in the business tourism industry there is a need for a fast and easy-to-use technology, from planning the journey, purchasing of flight ticket and hotel booking, to the organization of major events important for a corporate environment. In our days, innovation is no longer associated with major changes that affect a certain individual (OECD, 2004). It is related to the encoded knowledge and for the tourism industry, in the majority of cases, the product innovation is visible. Hall and Williams (2008) indicate the fact that we have innovation when a new way to solve a problem is found either by means of a new financial system for cost-reduction or improvement at the communication level. For tourism innovation, it is necessary that each experience of the tourist to grow; in the case where the products or services are improved, are more efficient, this is an added value to a particular product or service, new ways to resolve a problem, etc. For revival, the tourism industry Hjalager (2010) we identify the arguments by which the innovation in tourism can be met in: the product or service, the management or 
organisation process, in the management and institutional innovation. The most common type of innovation in tourism is the product or service in a percentage of 70,7 \% (Aldebert et al., 2011).

\section{Identification of the factors which contribute to the sustainability of the business tourism}

PICBE | 1108

We observe that the determinants which affect the dynamics and the efficiency of the business tourism are associated with the social and economic transformations of the society in the last time and they put their mark on the dynamics and the efficiency of this sector. According to Chiriac (2004), such factors as economic, social and political globalisation influence the flexibility in the realization of the market offers; the technological innovation, the internet and the artificial intelligence mean the use on a larger scale of these new means of communication causing the increase of operating speed in this sector. We notice the following hierarchy of the preferences of tourists in matters of travelling: the event related - business tourism on the 1st rank, followed by exotic destinations and holidays of short duration / city break. In order to become sustainable, the business tourism needs to aim at three directions: economic benefit, people (social) and planet (green). It is not only about economic profitability, its purpose is to meet the social needs, while the company also benefits. For this reason, let's take into account the definition of the sustainable development concept in tourism by Liu (2003): "All types of tourism forms (conventional or alternative), which are compatible with or contribute to sustainable development". This includes those companies that use sustainable practices in all types of forms: energy economy, water consumption, different types of transport, waste disposal, materials used for the construction, reduction of carbon dioxide emissions etc.

The role of the governments in the promotion and development of the national tourism is to create a sustainable economic development by the security and the quality of the services offered to the tourist, but also by an effective marketing strategy and the development of the infrastructure related to this sector. A common aspect of the partner countries of the World Tourism Organization in favour of economic growth is represented by the creation of new jobs by the tourism sector, but also by a preferential fiscal policy for tourists, through the reduction of taxes on certain products purchased during the stay (hotel, restaurant, traditional products). By encouraging traditional activities, particularly crafts and small traditional industry, it shapes the development of a specific trade based on the local and craft economical products, which lead to the sustainable development of the community. The sustainability of the business tourism is designed to protect the environment, which contribute to local and tries to increase the novelty of the tourist experience with the lowest possible impact on the nature (Honey, 2008; Liu et al., 2015).

\section{Conclusions}

The Romanian potential from the point of view of the business tourism development as a form of sustainable revival of the Romanian tourism is immense. With more so as the human, natural and cultural resources as they emerged from the data of the Report of the Commission for transport and tourism of the European Parliament, but also from the Report on the competitiveness in the tourism and the travel sector of the World Economic Forum on the years 2007 and 2015, are much more numerous than in the neighbouring 
countries. The purpose of this scientific process has been to deepen the role of the economic analysis in the field of tourism, in particular for the business tourism industry as a means of revival of tourist services.

A very important aspect for the business tourism industry is represented by the stakeholders in the field of tourism (hotels, carriers, travel agencies, event organising companies, restaurants, artists, translators, photographers, etc.) which have understood that this market is in a continuous development of the profitable business events so they have developed products in this respect. (Becker, 2013) It is to remember that the development of business tourism sector is in close connection with the infrastructure and the diversity of the services / benefits offered and contributes to the sustainable development of the communities where it develops its activity.

Because our scientific approach is linked to Romania, as a particular study in the future, we have identified various limitations of statistical, informational nature as topicality of the industry of the business tourism, facing the international market of this industry, where there are many authors who write about the development of the economic sector, where we can find examples success, as the USA, or countries of Europe, such as Germany and Belgium. This situation does not discourage us not to be the pioneers of a research of the evolution of the business tourism in Romania, as a sustainable way for revival of tourist services. The more so as Romania has real opportunities to become one of the most searched countries in Eastern Europe in terms of events and business tourism, because it is a destination with unspoiled natural, cultural and historical values, located in the European space easily accessible by air links with all European capitals, the infrastructure is in the process of modernization and the hospitality of the people is present in the hospitality industry. The result of the research shows us the ability of the business tourism to be sustainable in the context of the revival of the Romanian tourism.

\section{References}

Aldebert, B., Dang, R. J., \& Longhi, C. (2011). Innovation in the tourism industry: The case of Tourism@.Tourism management, 32(5), 1204-1213.

Becker, E. (2013), Over Booked the exploding business of travel and tourism, Editura First Simon \& Schuster, New York, USA.

Cristureanu, C. (1992). Economia și politica turismului internațional", Editura Abeona, București.

Chiriac, A. (2004). Asistență turistică în organizarea de evenimente, Editura THR-CG, București, 2004

Liu, C.H., Horng, J.S., Chou, S.F., Chen, Y.C., Lin, Y.C., \& Zhu, Y.Q. (2016). An empirical examination of the form of relationship between sustainable tourism experiences and satisfaction. Asia Pacific Journal of Tourism Research, 21(7), 717-740.

Davidson, R. (2005). Business Travel, Financial Times Managemet.

Davidson, R. Cope, B. (2002) Business Travel - Conferences, Incentive, Travel, Exhibitions, Corporate Hospitality and Corporate Travel, Prentice Hall Publishing.

Getz, D. (2003). Sport event tourism: planning, development and marketing.In S. Hudson (Ed) Haworth Publising, New York.

Hall, D., Williams, A.M. (2008). "Tourism and innovation”, London, Routledge. 
Hjalager, A. (2010). "A review of innovation research in tourism", Tourism Management vol. 31

Honey, M. (2008). "Ecotourism and sustainable development: Who own paradise?" (2nd ed.). Washington, DC: Island Press.

Liu, Z. (2009). "Sustainable Tourism Development: A Critique", Journal of Sustainable Tourism, vol. 11, no 6.

PICBE | 1110

Lu, J. Nepal, S. (2009). "Sustainable tourism research: an analysis of papers published in the Journal of Sustainable Tourism", Volume 17, Issue 1

Minciu, R. (2000). Economia turismului, Bucureşti, Editura Uranus.

Minciu, R. (2007). Economia turismului, Editura Uranus, Bucureşti.

Nistoreanu, P. (2005). Management în turism servicii, București, Editura ASE.

Swarbrooke, J. Horner, S. (2011). Business Travel\&Tourism, Publisher Routledge, London.

Master Planul pentru Dezvoltarea Turismului Național 2007 - 2026, http://www.mdrl.ro/_documente/turism/studii_strategii/masterplan_partea1.pdf, accessed January 20, 2017.

The Commission for transport and tourism. (2015). Propunere de rezoluție a Parlamentului European - Raport, Comisia pentru transport și turism, http://www.europarl.europa.eu/sides/getDoc.do?pubRef=-

//EP//TEXT+REPORT+A8-2015-0258+0+DOC+XML+V0//RO, accessed January 23, 2017.

Raport privind competitivitatea în sectorul turismului şi al călătoriilor. (2015). http://reports.weforum.org/travel-and-tourism-competitiveness-report2015/index-results-the-travel-tourism-competitiveness-index-ranking-2015/, accessed January 26, 2017. 